\title{
Eating the Asian Other? Pedagogies of Food Multiculturalism in Australia
}

\author{
Rick Flowers and Elaine Swan, University of Technology Sydney
}

\section{Introduction}

There is a long history in Australia of concerted efforts to construct food as a medium through which people learn about other cultures and as a sign, when they eat diverse cultural foods, that their cities and regions are more tolerant of difference. We call these efforts a public pedagogy for ‘official multiculturalism’ (Gunew 1993). Australian multiculturalism is highly contested and can refer to 'a theory, a policy and way of describing the fact of ethnic diversity in Australia’ (Carter 2006: 333). Official multiculturalism refers to policy attempts to 'promote' ethnic, cultural and linguistic diversity as ‘positive’ (Carter 2006: 333). By contrast, our use of public pedagogy signals the sites, processes and technologies of learning that happen outside of formal educational systems. These can include popular culture, museums, the internet, magazines, social movements, mass media, social media and the home (Luke 1996; Sandlin, Schultz \& Burdick 2010). Our work focuses, in particular, on food pedagogies (Flowers \& Swan 2012a, 2012b, 2013), and how food is used as a public pedagogy of multiculturalism. By this we mean the ways in which educational policy makers, the tourist industry, government and media promulgate the idea that by eating ethnic food we can learn about ourselves, the Other and their culture, or what Audrey Yue calls 'multicultural eating' (2003). One pertinent example of how this occurs in Australia was the 2011 Blacktown Multicultural Fiesta in Western Sydney, which aimed to 'Celebrate Blacktown's diversity through ... food stalls ... to generate awareness, build relationships and foster harmony amongst the different communities residing in 
Blacktown and elsewhere' (Wow Blacktown! 2011). As Sneja Gunew puts it, food has long been the banal, acceptable face of multiculturalism (1993: 13).

Nevertheless, such food multiculturalism has been subjected to trenchant critique by Australian academics (Hage 1997; Probyn 2000; Duruz 2010). These writers suggest that eating 'ethnic' food is a form of 'eating the Other' with problematic politics. The term eating the Other comes from the US critical race theorist, bell hooks (2001). She argues that the consumption of racial difference by white people is now seen as a source of pleasure. In particular it represents disaffection with dominant white culture. Thus, she writes, 'within commodity culture, ethnicity becomes spice, seasoning that can liven up the dull dish that is mainstream white culture' (1992: 21). She asserts that eating the Other is a narcissistic project of self-development for the white person. Drawing on hooks's idea, several writers on food and multiculturalism argue that white people's practice of eating the Other is not de facto learning about the Other. Hence, you can have 'multiculturalism without ethnics' in which food is abstracted from any notion of cultural history, colonialism and inequalities (Hage 1997). In this view, culinary cultural exchange is not progressive: the proliferation of eating ethnic food is not seen as a signifier of understanding or a shared future (Cook 2008). You can eat the Other but keep your border (Bost cited in Cook 2008: 3). This view, however, is subject justifiably to some debate.

Some writers see possibilities that eating and cooking ethnic food can facilitate productive inter-cultural exchange in spite of uneven power relations. This may be understood as a result of emphasising 'ethnic power.' Uma Narayan (1997), for example, emphasises the ways in which ethnic restaurateurs have agency in deciding what food to serve white people, inventing new recipes, using different ingredients and making hybrid dishes to make a profit. She argues that while eating ethnic food may be 'shallow, commodified and consumerist ... it seems preferable at least to the complete lack of acquaintance' (1997: 180). Other critics argue that the consumption of ethnic food shows white agency to be more fragile and fragmented than may sometimes be imagined. Thus, Jean Duruz's (2007) work suggests that the white person in an ethnic restaurant is not always the active subject and that there is more blurring and ambivalence in food encounters than some authors credit. Yet others argue, as does Ian Cook (2008), that eating the Other reproduces reductive, purist, static and essentialist 
notions of ethnic groups and their ethnic foods. The work of Narayan, Duruz and Cook draws our attention to everyday multiculturalism. This is the multiculturalism that does not just happen in public events like festivals or public places like restaurants, but also in the intercultural encounters that take place in day-to-day happenings at work, in the family, or on the street. And so we think it important to focus on everyday intercultural food pedagogies, and not just public pedagogies of official food multiculturalism. Our focus on everyday pedagogies is not, however, to presume that the everyday is innocent but to ask how power and politics play out in concrete ways in everyday, daily multicultural interactions (Hage 1998; Martin 2003). As Hage notes, everyday multiculturalism includes conflict and racial intolerance that official multiculturalism occludes from its national pride stories; but it also includes matter of fact, intercultural and interethnic encounters that do not smack of triumphalism (Hage 1998; see also Carter 2006).

We argue in this paper that what needs more examination in Other-eating is the process of Othering and the specificities of the Other in these everyday interactions. Influenced by Narayan, Duruz and Cook, we do this by emphasising the importance of examining Anglo-Australian whiteness and white food as 'ethnic.' We think these writers encourage us to think about less usual, and perhaps more productive, ways of understanding the complexities of ethnicities. We also reflect on the specificity of the Other's ethnicity and gender in relation to Australian history and racism and individual memories. Sanjay Sharma (2006) argues that we need to differentiate between the ontological abstract general Other and the concrete Other in life. Multicultural pedagogies, in his view, have scarcely considered on what 'ethical' grounds otherness has been engaged. Everyday multicultural theories focus on this concrete Other in terms of social agency (Sharma 2006). Self and Other are thus better understood in identity formation theory as relational, and in this paper we ask how we can understand Othereating when relational identity formation involves and implies a range of personal relations, for example, when the Other may be your mother, wife, best friend, fellowstudent or child? What happens to the idea of eating the Other when you live, work and eat in other countries, as opposed to merely eating out in restaurants in Australia? What might this more complex understanding of everyday eating the Other mean for food as a pedagogy for understanding multiculturalism? 


\section{Research focus}

To these ends, in this paper our discussion is grounded in a study of Frank (pseudonym), a white Australian man who married a Chinese student from Singapore in the 1950s. The data in this paper draws from a research project on food pedagogies that includes a study of mixed-race family eating. This paper draws on one story in this study: that of Frank. His narrative stretches over 70 years, covering different multicultural moments in Australia's history and across the many different countries in which he lived and worked. We chose to study Frank because the sort of intercultural encounters he experienced are paid relatively little attention by writers in the field of multiculturalism. He not only formed friendships with Chinese people in Australia that endured from his early 20s to the present day, but he married Ching Yu (pseudonym), a Chinese student with whom he had two mixed race children. Frank had a career as a senior administrator that included overseas business travel starting in the 1960s, and postings on foreign aid projects for several years at a time in Kenya, Tanzania and Indonesia, living as an expatriate worker with the privileges that this bestows. His second marriage was to Cory (pseudonym), a Filipino migrant in the 1970s with whom he also had two children.

It is important to note that Frank's story involves friendships with Asians, living with Asian women and living in parts of Asia. We recognise the problematic nature of the generic terms Asian and Asia but use them to highlight how they operate in the white Australia imaginary (Ang 2000). Thus, Australia has a history of profound ambivalence towards Asia, at once 'anxious’ about Asia, Asians and in particular the Chinese, and yet also keen, in some quarters, to embrace Asia economically, culturally, and somewhat more complexly, erotically and sexually (Walker 1999). The White Australia policy of the early $20^{\text {th }}$ century reproduced the idea that 'the very presence of Asians was considered a blemish on the ideal image of the white island continent' (Ang 2000: xiii). As Catriona Elder writes 'The fantasy of a clearly bounded and inviolable national space has underpinned many of the ideas that white Australians carry with them of what it means to be “Australian”' (2003: 223). The Chinese were constructed as profoundly Other in the tradition of Orientalist knowledge, a 'Western style for dominating, restructuring and having authority over the Orient' but inflected in particularly Australian and colonialist ways (Said 1978: 3; Anderson 1999). There has been for many years in Australia, then, the view of an 'obvious and threatening otherness of Asians' (Perera 1999: 189), although there has also been a turn to Asia 
from the mid- $20^{\text {th }}$ century onwards in which a new pro-Asia Australia was seen as representing a break from Britain and its racist past and the embrace of a new multiculturalism and independence (Carter 2006), This stance was particularly strengthened in the 1990s under the Labor Prime Minister Paul Keating. Elder (2003) has highlighted the ambivalence of Australia’s desire for and fear of Others. She reminds us that this desire and fear is gendered: female Asian Others were seen as less threatening than their male counterparts. In spite of the idea of 'Australia in Asia' and 'Asia in Australia,' several commentators note that there is still a deep-rooted fear of the Asianisation of Australia (Ang 2000; Docker \& Fischer 2000). Frank’s life needs to be understood against this backdrop. The variegated intercultural food encounters with their specific ethnic and gendered dynamics in Frank's life, and the historical and cultural conditions through which they were produced, is under-researched in the literature on food and multiculturalism. Much of that literature has focused on white Australians who have superficial or commodified food relationships with the Other. Frank's story represents a more complex story of Other-eating at home and in the public domain, the dynamics and character of which are unusual but not unique.

To start exploring these issues, our article is structured as follows. First we provide an in-depth review of three influential accounts of 'Eating the Other' and the debates on this as a politics of anti-racism. We follow this with an in-depth discussion of our methodology and its rationale, and then a close reading of Frank’s story, asking what difference his memories, relationships and travels makes to eating the Other across different historical and cultural moments.

\section{Eating others}

In this section we provide a close reading of three influential authors who write on the politics of eating ethnic food. None of these authors position their analysis through an educational frame; but influenced by what Michael Welton calls a 'learning optic' (2003), we as adult educators can see a strong theme of pedagogies underpinning the writers' arguments that we amplify in our paper to examine multiculturalism and food.

We kick off with the work of the US philosopher, Lisa Heldke (2003), who has interrogated the colonial politics in the middle-class project of cooking and eating ethnic foods. She observes that it is often foods of "economically dominated or "third world" cultures' that are so readily consumed by white, middle-class Americans. We have 
already mentioned Heldke's and hooks's widely cited argument that white, middle class people are ashamed of their white food heritage. An influential concept in Heldke's work is the idea of 'food adventuring.' She uses this to get at the way that white people experiment with eating 'novel,' 'authentic,' 'exotic' and 'dangerous' ethnic foods. She defines food adventuring as 'in part an attitude, a particular spirit or disposition' (2003: 5) to reading cook books, talking about food, and going to restaurants. Colonial food adventuring is a pedagogical project inasmuch as gaining knowledge about food, ingredients, chefs and the 'latest thing' is central. For Heldke food adventuring is a middle class project of pursuing status distinction and cultural capital. Capital comes from the counter-cultural status of displaying knowledge about new ethnic ingredients, foodstuffs or restaurants. It also has a firmly masculine ethos. This is evident, for Heldke, in the 'bravery' required to try new foods, and the 'quest-like nature of food adventuring involving single-mindedness and drive' (2003: xxiii-xxiv).

In the food adventuring project, people who are not white become a resource that aids white food adventurers in the quest for novelty and their desire for authenticity. The equalising of novelty with notions of the exotic is quintessential for the food adventurer in Heldke's view. Eating exotic foods is an exclusive and excluding project. Status must always be out of reach for other groups. Thus, displaying ethnic food knowledgesexperiential, book and gustatory — is always a 'catch-up tool' given that there will be invariably another obscure or strange foodstuff on the colonial horizon (Heldke 2003: 17). It is a moving feast. The novel food can all too soon become the familiar and the dull, just like mainstream white food. Novelty has a shelf-life.

For the food adventurer, according to Heldke, food, ingredients and restaurants also need to be 'authentic.' But authenticity is in the eye and tastebuds of the white eater. The pursuit of authenticity can lead white adventurers to essentialise the Other because they seek some 'pure, unchanging, authentic essence' that, in fact, 'does not exist' (Heldke 2003: 33). It is the preservation in aspic of a fantasy of the Other. For Heldke, then, food adventuring today is following a white colonial practice of exploiting the Other. It abstracts the presence of ethnic food from historical and political context. For example, sitting behind the availability of Burmese food in North America is a history involving the enforced dislocation of migrants or refugees from their own country. The Other's cultures are taken out of people's lives, traditions and continuities and reduced 
to a resource for a white project of self-realisation, development and status enhancement. Culture is 'as a source of materials to be extracted and used to enhance our own cultures’ (Heldke 2003: 43). Food adventurers, like colonisers, have always seen everything they found as a resource to take and use.

There are moments, however, when Heldke emphasises the agency of the other. Ethnic restaurateurs can direct eater's tastes. This may be on the basis of cost, profit or labour intensity. As she says: 'Members of colonized societies are [not] all and only helpless pawns in the exoticisation process' (2003: 20). In her book Exotic Appetites, while critical of middle-class food adventuring, Heldke wants to hold onto some crumbs of comfort by articulating what we might call a pedagogy of anti-colonial eating: a way to have your ethical ethnic cake and eat it. She argues, in a somewhat jejune way, that this mode of eating is about fostering respect for one's own traditions and cultivating an openness to others without objectifying them (2003: 168).

Heldke's work takes the aphorism and metaphor of eating the Other and investigates it empirically and autobiographically. The context, however, is clearly US-centric with its own colonial histories and particular Indigenous, ethnic and migrant relations. We need to ask how these insights relate, or can be translated, to an Australian context. How do the eating practices of Australian white food adventurers differ from non-white restauranteurs - those whose food is being eaten? Is it possible to have different intercultural food encounters that are not simply dismissable as colonialist? To respond to some of these questions, we turn to the Australian cultural studies critic Ghassan Hage (1997) and his influential account of the classed and racialised politics of food multiculturalism as they modulate what he calls migrant home-building in Australia.

\section{Cosmo-multiculturalism and home-building multiculturalism}

Drawing on interview data with Lebanese migrants, restaurant staff and white Australian customers who visit restaurants that serve Asian and Middle Eastern cuisine, Hage (1997) coins the term 'multiculturalism without ethnics' to get at a number of dynamics in ethnic food eating amongst the white middle classes in inner Sydney. In particular, he sees a conflation between cosmopolitanism and multiculturalism in Australian policies and the self-presentation of middle-class eaters. In his argument, this leads to an elision of cosmopolitan eating, multiculturalism and anti-racism, a disposition he calls cosmo-multiculturalism. Cosmo-multiculturalists assume that if you 
eat ethnic food then you will learn about different cultures. Although Hage does not use the term pedagogy, we can situate food cosmo-multiculturalism in a longer trajectory of Australian multiculturalism pedagogies, in which food is seen as mechanism for enabling empathy, tolerance and connection across different ethnic groups (Gunew 1993; Swan 2007).

Hage argues that the celebration of ethnic food becomes about tourism and marketing, not intercultural encounters: 'Cosmo-multiculturalism, like cosmopolitan eating elsewhere in the world, has more to do with the market of foreign flavours than with the market of "foreigners"' (1997: 120). Furthermore, when multiculturalism becomes a marketing project it becomes something that white, middle class people control, rather than what migrants do in everyday settings.

At the centre of this project, for Hage, is the treating of the Other as an object for personal enrichment and class distinction. Thus he writes 'the cosmopolitan relation of consumption is itself grounded in an inter-ethnic power relation which [sic] allows for the availability of ethnicity as an object of appreciation by the cosmopolitan subject' (1997: 100). One element of this relation is 'that the dominant multicultural discourses of food are eater-centred, and they vary in the degree to which they emphasize ethnic feeders as active central subjects' (1997: 118). White working-class residents in outer Western Sydney, who do not frequent ethnic restaurants as much as middle class residents in inner Sydney, are seen by middle class ‘adventurers’ as less multicultural, even racist 'on the basis of their assumed inability to appreciate cultural diversity' (1997: 100). He writes that 'such claims are only possible from the vantage point of a reality which involves minimal inter-cultural interaction between cultural subjects' (1997: 100).

The consequence is twofold: first, actual homebuilding and the eating practices of migrant groups are not seen as part of multiculturalism by food adventurers. In contrast, Hage writes, 'multiculturalism in Australia is, or at least ought to be, above all about migrant lives and intercultural interaction’ (1997: 118). Hage draws on his data with Lebanese migrants to argue that another version of multiculturalism takes place in people's homes. These are 'encounters that constitute a homely and an interactive culinary multiculturalism, based on interaction between different cultural subjects' (1997: x). This is home-building multiculturalism and it involves making traditional and 
new types of food at home, for the family and Lebanese friends, and sometimes, for Anglo-neighbours. Although Hage claims that he does not want to romanticise homebuilding multiculturalism or denigrate cosmo-multiculturalism wholesale, the overall effect of his argument is to set up a binary where home-building multiculturalism is seen as good and cosmo-multiculturalism seen as pejorative.

Hage's argument that cosmo-multiculturalism is practised without migrants begs the question: what happens if an Australian descended from white Scottish and English descendants who came to Australia four generations ago, and a recently arrived Chinese, and then a Filipino, migrant are in the same family? Hage writes about Lebanese migrants who make friends with and marry other Lebanese migrants, and likewise white Australians whose family and friends are also white. His analysis rests on a contrast between homely multiculturalists who eat in, and cosmo-multiculturalists who eat out. But what if we examine an eater who not only does both, but also has inter-cultural encounters in both domestic and public settings? We note, too, that in spite of much feminist writing on gender and food, Hage does not examine the gendered dynamics of feeding and eating across these different sites, nor the specificities of what we might call 'gendered cosmopolitanisms.' In contrast Heldke describes food adventuring as masculinist. To challenge some of these critical assumptions, we turn to the work of Jean Duruz.

\section{Fragments of memory}

Jean Duruz is an Australian cultural studies theorist with an extensive body of work on food, memory and 'exotic eating.' Her overall project is to trouble analyses about eating the Other. She does this by problematising certain taken-for-granted categories and binaries in writing on race, food and colonialism. For example, Duruz (2010) questions assumptions (both popular and scholarly) in which the 'cosmopolitan' and 'migrant' are positioned as fixed, opposing categories. Central to this methodology is the power of memories and imagination in making food identities, cultures and places. Race, gender and difference are critical to her analysis. She is interested in tracing ambivalence and blurring in the 'minutiae of everyday life' and what those traces mean for racialised and ethnicised politics and relations.

Duruz’s work examines both public and everyday pedagogies of food and multiculturalism. She aims to use everyday narratives to disturb the 'celebratory 
discourse of food writers, tourism professionals, community histories, local councils' (2010: 52). Her intention is to 'seek out unpredictable or disruptive moments of storytelling to "unsettle" assumptions that eating from the so-called "mainstream" does not also have its own "ethnic” boundaries to confront' (2010: 54). She wants to scrutinise "the everyday, lived experience associated with "mainstream” ... “Australianness”” (2010: 57). This is a political and intellectual project that involves emphasising the ambivalence of inter-cultural food encounters, the agency of different ethnic groups and the openness of identity. This means, for Duruz, 'the need to reincorporate "mainstream" identities and experiences into images, discourses, and the meanings of ethnicity' (2010: 57), but at the same time to show white ethnicity as fragile, fragmented and complex. In similar vein, we focus our discussion on Frank's stories and the nature of his fragmented and complex, white Anglo-Australian 'ethnicity.'

Duruz analyses what she calls fragments of memory: data on dreaming, remembering, reflection and storytelling. But these are not simply individualistic or psychological but 'fragments of personal mediations of public meanings' (2010: 53). Thus, they constitute 'memories of other times and places: landscapes of imagined possibilities, threaded through with the dense imagery of global and local media discourse' (2010: 53-54). These stories offer a glimpse of power but are not intended as definitive or representative ones: 'Instead, stories are both complicated and speculative, their details allowing reflection on broader questions’ (Duruz 2001: 29).

Across Duruz's work, we meet a number of different people as they talk about markets, favourite foods, shops, ingredients and meals. The gender, race and class of the narrator affect whether one is seeing what she calls the 'cook's eye view' or the view of the one fed, comforted and nurtured. As she sums it up, 'crudely put: it's often better to eat than to cook, to be served than to serve' (Duruz 2001: 24). Duruz suggests that if we listen to these stories closely with our ear to the ground, they offer 'curious and disturbing nuances' (Duruz 2010: 45). There is an 'oddness' to such stories that encourages us to think about less usual, and perhaps more productive, ways of understanding the complexities of ethnicities.

Duruz (2010) draws on post-colonial writers to emphasise entanglement and 'inbetween.' These complicate such binaries as 'homely'/'exotic,' 'style'/'embodiment,' 
and 'British'/'Asian.' She emphasises how the blurring of identity boundaries might enable us to “imagine different politics of eating and different "entangled” cartographies of transnational belonging' (Duruz 2010: 48). Building from Ien Ang’s work (2000, 2004) Duruz wants to underline that all cultural groups are 'impure' and all cultural boundaries are potentially 'porous.' Cuisines, too, for her are 'hybrid' and involved in 'messy boundary crossing,' rather than being 'fixed' or unproblematically 'authentic.'

\section{Methodology}

In this next section we provide a comprehensive summary of our research approach and methodological decisions, giving more information about Frank. In particular, we focus on four aspects of our research: background to the research on which this paper is based; biographical information about Frank; a summary of our method and our focus on food memories; and our approach to interpreting the data.

The data in this paper is drawn from a wider program of research that explores what we call food pedagogies in which we are interested in the proliferation and intensification of public, family and everyday pedagogies of food (Flowers \& Swan, forthcoming 2013). This program covers a range of sites, media, and 'teachers' and 'learners' from social activist films (Flowers \& Swan 2011) to ethnic food tours (Flowers \& Swan 2012). In this particular study we focused on one Anglo-Chinese Australian mixed race family and undertook interviews with the Anglo-Australian father and two mixed race sons. Our study was motivated by our sense of dissatisfaction with the some of the discussions on 'eating the Other' in the literature, the lack of attention given to men, masculinity and mixed-racedness in food studies and family studies. Our intention at the start of our work was not to research food memories in a mixed-race family but this developed as we interrogated some of the assumptions in the literature, and were motivated by our own interest in processes of racialisation and gendered hierarchies. Frank was chosen because he is from a mixed race family and we wanted to investigate what happens when white Australians have friendships, work alongside and marry the Other as a way of 'testing' out current thinking on eating the Other. There were pragmatic reasons for choosing this family: they are known to one of the authors and we were able to contact them and organise the interviews with them relatively easily.

This paper focuses on Frank rather than the family per se, for three reasons. First, we want to analyse distinct ethnicities and their specificities in some depth. Jean Duruz has 
written about the importance of using individual storytelling to 'unsettle' assumptions that eating from the so-called 'mainstream' does not have its own 'ethnic' boundaries to confront' (2005: 54). Thus, she suggests that an important political project is to scrutinise 'the everyday, lived experience associated with “mainstream” "Englishness” and "Australianess"” and 'the need to reincorporate "mainstream" identities and experiences into images, discourses, and the meanings of ethnicity’ (2005: 57). We agree that it is an important political project to relativise and denaturalise the stories, experiences and meanings of white ethnicity in relation to food. Hence, we focus on Frank’s Anglo-Australian masculinity in relation to food and multiculturalism. Second, in focusing specifically on his stories, we wanted to interrogate the dynamics, specificities and relations of Othering rather than assume a static Dominant-Other relation. Third, Frank has lived through various official and everyday multiculturalisms, and in various colonial and postcolonial countries. These experiences are rich and complex, and present a challenge to theorise. It is usual practice in life history and memory work to focus on one single individual story (Cresswell, cited in Miller \& Deutsch 2009). We felt, therefore, that we could do justice to Frank's stories and those of the sons by separating them into two separate papers. ${ }^{1}$

Our method has been termed culinary biography interviewing (Duruz 2010; 2011). Culinary biography interviewing draws on people's stories and memories about food and their lives. It can focus on the meaning that food, food rituals, food preparation, food consumption and food products have in individuals' lives, and it may be presented chronologically and thematically (Miller \& Deutsch 2009). We were particularly inspired by Duruz's notion that dreaming, remembering, reflection and story-making in relation to food-what she calls 'fragments of memory'-are important. They offer insights into 'everyday imagined geographies of 'Englishness' and 'Australianness' and offer 'personal mediations of public meanings' (2010: 53-54). The connection between what have been called 'small stories' and ‘micro-histories' and an imagined 'macro' context is much discussed in the narrative literature (Cameron 2012). These small stories can be affective and political in their own right, not simply as exemplifications of larger scale discourses, but important for their detail, smallness and everydayness (Cameron 2012).

\footnotetext{
${ }^{1}$ The second paper is entitled 'Potatoes in the Rice Cooker: Mixing Through Family Food Pedagogies,' and is currently under review for journal publication.
} 
We undertook two interviews with Frank totalling five hours. We were interested in Frank's memories of food in his childhood, his mother and her cooking, his adult family life, his business and personal travels. We asked Frank to talk about eating in (at home) and out (in restaurants and functions). More specifically, we designed a semi-structured set of questions - informed by literature on gender and cooking (Sheridan 2000; Supski 2007) — which sought to encourage Frank to recall accounts of food he ate, made and purchased.

We had hoped, having read the evocative and sensuous accounts of eating in Duruz's respondents (2005) and Sutton's anthropology of Greek women (2001), that Frank’s memories of the women cooking in his life would be rich. But contrary to other food memory research, Frank did not present his memories of either food at home, or the women cooking home-cooked food, in a sensuous idiom or detailed language. Even with our feminist training, we were surprised by the lack of concrete detail in Frank's accounts of eating food at home. As a result, during the interview and in a follow up interview, we moved our focus more directly to talking about Frank rather than the women in his life. Methodologically we started to examine different literatures for our analysis and interpretation. There are, of course, ontological and epistemological debates on the interpretation of data, and in particular data drawn from individual memories. There are also, as feminists have argued for many years, a politics of interpretation. It is to these two issues, we now turn.

The ontological nature of memories has been much debated by oral historians and other social theorists (Polkinghorne 1998: Plummer 2001; Holtzmann 2009). There are two key foci in these debates. One refers to the nature of narrative truth and the other, the nature of memory. For Plummer (2001), the nature of 'truth' is about the intersections between lives as lived, lives as told and lives as written. He argues that most life history researchers agree that it is not possible to get at historical truth though oral history. The key issue for many researchers is that life is not simply lived, it is told. So a life as it is lived is created through autobiography. As Plummer writes, 'our lives are constructed, fabricated, invented, made up-this does not mean all the stories we hear have to be seen as equally valid or invalid, truthful or deceptive' (2001: 238). This means that we need to understand 'truth' in life history as a multifaceted concept. Italian oral historian, Allessandro Portelli, says that life stories are always 'artificial, variable and partial' 
(1998: 72). Yet, even factually inaccurate statements can have a psychological truth. This truth, he emphasizes, 'may be as important as factually reliable accounts' (1998: 68). Plummer (2001) sums up it by saying that life historians need multiple criteria for understanding the nature of truth that mediates living, writing and telling.

There is an important ontological question about the nature of memories. Like truth, memory is a multi-faceted concept, which refers to distinct dynamics and processes that are framed by cultural conditions and practices. As the anthropologist Jon Holztman has written, the term memory can include 'events that subjects recall or emotionally reexperience, the unconscious (perhaps embodied) memories of subjects, how a sense of historicity shapes social processes and meanings, nostalgia for a real or imagined past, and invented traditions' (2009: 363). Our focus is on memory talk—narrative memory — rather than other more sedimented memories because memories are not just cognitive (Sutton 2001). They can be embodied and rely on emotional experiences that are provoked by smells, sights and touch. This is the particular significance of food in relation to memories. Food is potentially sensuous. As Holtzman says, 'food, offers a potential window into forms of memory that are more heteroglossic, ambivalent, layered, and textured' (2009: 373). In sum, recalling memories is active, and performed through cultural genres including culinary biographic interviewing.

The second methodological issue we wish to discuss is the politics of interpretation. There are, of course, debates about the political and ethical relations and processes involved in research, theory and knowledge production. These include discussions on the methods of collecting data, the choice of respondents, the editing of materials, the selection of quotes, and the use of theoretical sources in the interpretation of respondents' accounts, and the methodological narratives of the research. As feminists such as Beverly Skeggs (1995) and Jackie Stacey (1995) have noted, research is not the smooth, linear, seamless process that is often presented as cleaned-up methodological sections in academic papers and books. These accounts may occlude 'the dead-ends, the U-turns, the frustrations and the despair,' and under-represent the 'haphazard and arbitrary' (Stacey 1995: 100). These aspects of research describe our own experience in this study. For example, we began with the aim to analyse memories of women cooking in families, and yet we had to change the focus of our study when our respondents had wills and minds of their own, and did not fit their responses to our initial, neat and tidy 
research question. We had been inspired by the sensory and evocative data in the work of Sutton and Duruz; but we were perplexed when Frank did not invoke food in sensual or colourful detail, and nor did he talk much about his mother. This had two effects: first we were impelled to undertake a second interview to ensure that our questioning technique was not responsible for Frank not talking about food as we had hoped; second, we were obliged to draw on a different range of conceptual resources for our interpretation.

The interpretation of data is much discussed in feminist theory. There are concerns about the power of the researcher presenting the ideas and feelings of their respondents and using the theoretical resources to interpret the material. This is usually in relation to women interviewing women, in which there has been a tradition of assuming rapport and common ground between women. More recently, that stance has been subject to some critique particularly in relation to the power of researchers to interpret data. In their take on these issues, Jackie Stacey (1995) and Ann Gray (2003) are committed to the importance of critical distance between researcher-account and respondent-account. Gray, for example, argues that 'there is a fine line to be negotiated between the desire to honour and acknowledge the ... personal accounts given by individuals... and the desire to analyse and critically interpret those stories’ (2003: 124-25). Bridget Byrne (2006) makes the point that researchers may be interested in areas that interviewees do not see as significant and will sometimes see the need to analyse the interview with a quite different emphasis from the interviewee. For Stacey, the role of the researcher is to produce new or refined categories by working dialectically between data and theoretical sources. In her view, the researcher has a political and ethical obligation to 'use a critical framework which is appropriate to the material and which is made explicit and which can be contested' (1994: 157). None of this means that ethical considerations in relation to interviewees and data are not important. As Byrne argues, it means being sensitive to the complexities of the interviews and involves 'careful, and sometimes painful, work' (2006: 38). Our data analysis and interpretation mirrors this approach.

Our interviews were audio-recorded and transcribed. We analysed the data in several stages, using traditional methods of reading, highlighting and coding themes in the interviews and working dialectically with literature. As a result, we coded Frank’s interview in a fairly traditional way, by identifying themes and doing a close thematic 
analysis of the transcript data. We chose quotes that we felt best exemplified themes or contradictions in his account, and that connected back to our reading in some explicit or even tangential way.

Below we provide a detailed reading of the data through a number of themes. We have organised these structurally to relate to the literature review. This may give an overly tidy and teleological 'feel' to the paper; but we want to be clear here about the ideas that motivated the research, and with which the data is put in dialogue in order to extend, challenge and build new categories and understandings.

\title{
White food
}

\begin{abstract}
We used to go to ... my grandmother's place often of a Sunday night for dinner. One of the features was her pear tarts and apple pies. We enjoyed that. She put on a prolific spread on a Sunday night. Cold meat ... scones and pies and things.
\end{abstract}

This quote from Frank about food from his childhood is in line with one construction of traditional Australian Anglo-fare as good, 'hearty, filling, tasty’ (Duruz 1999: 236). As Duruz notes, food writers and historians suggest that the 'pudding' is central to the earlier Australian diet given its 'overtones of indulgence and excess' and key place in nostalgic remembering (1999: 236). The other construction of Anglo-food is as bland and poorly cooked, 'a cuisine of conformity, curiosities and leftovers' (1999: 237), in contrast to ethnic foods that are depicted as interesting, modern and spicy. One theme in the literature about food cosmopolitanism is that white people are bored and even ashamed of their food heritage (hooks 1993; Heldke 2003). This type of narrative underpins theories that suggest certain classes of white people are keen on ethnic food because it offers them a way of escaping their heritage.

In Frank's case, he has fond memories of the Anglo-food of his childhood:

Then we continued the tradition that had been part of the family eating history where Saturday night was roast dinner. So we had usually beef or lamb, occasionally pork, and we would have that almost always with baked potato, baked pumpkin and one other vegetable... there was always more that could be eaten in one meal, so it constituted the basis of cold meat and salad on Sunday night.

Frank describes his mother's home-cooking in more detail than that of his Asian wives. This could be interpreted as evidence of pride and affection for his Anglo-Australian food cultural heritage. Several authors (Sutton 2001; Duruz 2005; Chan 2010) have 
written about the nostalgia for childhood food in cookbooks and memories. As Selina Chan (2010: 212) puts it 'imaginary reconstructions of the past are created' as nostalgia for the extended family. She goes on to suggest that 'nostalgic food remembrance often reveals a contrast between a golden past and a present loss, in which psychological comfort is derived from remembering the past' (2010: 210). But does Frank’s data do this kind of 'comfort remembering'? We suggest not. In opposition to much recent writing on the sensuality of food memories, the way Frank presents his account is spare and 'factual.' He lists foods rather than describing them in today's discourses of middleclass embodied foodiesm and the retro-romanticisation of home-cooking (Duruz 2001). Rather the litany in Frank's accounts of Anglo-foods and the repeated word 'always' point to a repetitive rhythm of food habits in his early food biography. Unlike Alice, the Anglo-Australian female respondent in Jean Duruz's research, who is of a similar age to Frank and continues some of her mother's Anglo-food traditions, Frank presents himself as having little inclination in upholding Anglo-food habits: quite the contrary.

Thus, in this next quote, Frank talks about food with his first wife who was Chinese. When asked whether she learned to cook Anglo-food, he said: 'I never expressed any need to have an Australian type menu in the house. So Ching Yu determined what happened. But after Ching Yu died I can’t remember that I cooked potatoes at any time either. Rice was the staple.' Freighted by patriarchal gender relations, this quote represents a clear refusal of his Anglo-Australian food heritage. It contrasts with the bounty listed by him of his mother's house. We observe that Frank does not present memories of meals, let alone smells and colours, and gives a terse account only of one ingredient, namely rice. Ang (2004) suggests that culturally potatoes are the signifier of Celtic-Anglo food and rice of the 'Asian.' Of course, millions of descendants of the Incas who first cultivated it in the Andes also identify closely with the potato. Rice has long been eaten widely across Latin America, the Caribbean, Spain, Italy and Greece. But in much of Europe and Australia, as Ien Ang writes: 'rice arguably sets Asians apart from westerners as well as from other non-westerners such as Arabs and Africans. Indeed, rice is a widely applied popular marker for Asianess in the west ... [it is] the prime emblem for Asian cultural specificity and difference’ (2004: 149-50). Frank’s description needs to be understood in the context of rice not being commonly eaten in savoury dishes - notwithstanding the longer history of rice puddings - in Australian households until the 1980s. Susan Sheridan reminds us that from the early 1960s recipes 
and advertisements in the Australian Women's Weekly—an iconic and popular magazine - tried to 'persuade Australians to consider rice as one of their staple dietary ingredients' in order to demonstrate being modern and cosmopolitan (2000: 323). In contrast, Frank suggests that eating rice was a mundane everyday fact of life. Rather than presenting himself as educated by a feminine domestic pedagogy to eat rice, Frank positions his own turn to Asian food in the context of public masculine friendship in the 1950s, which we discuss below.

\section{Ethnic food socialities}

One of the criticisms in the literature around eating ethnic food is that white people have superficial relationships with the Other when they eat in restaurants in the public domain. For Hage the migrant's home is where there can be a more genuine, uncommodified and meaningful multicultural sociality around food. The fieldwork Hage drew on for his paper, 'Entrails of the West,' was undertaken in the 1990s. Frank married a Chinese student in the 1950s. Over the span of his adult life, Frank did not make a habit of going to 'ethnic' restaurants. Instead he went to 'ethnic' countries, made friends with 'ethnics,' and married two Asian women. Of course, power relations of variegated kinds are part of these food relations. The specificities of imperial-colonial, gendered and racialised power relations are important to think through when examining food multiculturalism and its socialities.

Unlike Hage's and Heldke's critique of food adventurers and cosmo-multiculturalists as doing food multiculturalism without ethnics, Frank presents himself as being introduced to Chinese food through friendship. 'So my best friend Ng Yen Hock was the one who took me for my first Chinese meal. We went to Lygon Street, Carlton and we had egg fuyung. I thought that was very exotic at the time.' They are eating out; but what we see is an 'ethnic' in Melbourne taking a white Australian to a restaurant. This represents a different picture of the 1950s from that summarised by Duruz: 'It is a sober thought that for many Australians, the fifties are emblematic of the longing to return which involves a celebration of conservative relations, particularly of gender and ethnicity-a celebration of 'wogless,' white Australia and of ‘family values’ (1999: 250).

Frank then tells us a different 1950s story about Australian multiculturalism, namely, a turn to Asia exemplified by the Colombo Plan, the Women's Weekly cosmopolitan modernity project, state-sanctioned pride in food diversity at the 1956 Olympics, and 
increasing embarrassment with the continuation of a White Australia immigration policy (Jayasuriya \& Pookong 1999; Ang 2003; Elder 2003). As Elder writes: ‘This decade was one where the "white Australia” policy had to be represented to the world and to the nation. The horror of the Holocaust made blatant and crude racism more difficult to present as good government policy’ (2003: 235). Frank does not treat Asian immigration with suspicion, or as a narrative of national decline; he presents us with a story of ethnic food socialities taking place earlier in the history of multiculturalism that is relatively under-discussed in the literature.

These food socialities are further complicated in this next quote in which Frank talks more about his Chinese friend:

Ng Yen Hock used to eat Greek food, particularly a restaurant immediately opposite the Melbourne Public Library. It was Greek food with rice as the staple and with lamb. He and I used to go together to that particular restaurant. I don't remember going to another one, but we often went there because it was opposite the public library. I don't know how he discovered it but he took me there. So it became a fairly regular part of our thing.

Is this food adventuring (Heldke 2003) or multiculturalism without ethnics (Hage 1997)? Frank’s narrative does not seem to exemplify either critical approach. Here we see a Chinese student based in Melbourne adventuring into Greek restaurants. In her discussion about ethnic friendships and food between women, Duruz (2005) shows how Alice and Stella, Anglo and Indonesian Australian friends, interact through a feminine exchange of recipes, ideas, knowledges, caring through shopping, eating out and eating in. Frank and Yen Hock participate in a masculine economy of exchange in their eating out. But in contrast to Duruz's respondents, Frank gives sparse accounts of his food exchanges: there is little recounting of taste, smell and colour or the nature of the friendship. For Fiske, Hodge and Turner (1997), historically Anglo-Australian masculinity is marked by inexpressivity; in Frank’s case, this represents a pre-foodie, pre-Jamie Oliver masculininty. Frank had a life long friendship with Yen Hock, so there is a deep relationship here despite Frank’s sparse and matter-of-fact narration.

An important aspect of Frank's story is that it enables us to begin to historicise food multiculturalism in Australia. First, historic forms of white Anglo-Australian food masculinity may not be rich in detail and sensuality unlike those of TV chefs today and the women in Duruz' research. Second, this historicisation points to the emergence of deeper and earlier forms of inter-cultural food interactions than has been discussed in 
some of the literature (Hage 1997). Hence, in his story we see a white Australian man who turns to Asia in an everyday, lived and embodied manner not only through friendships, but through marriage, and living and working in Asia starting in the 1950s. Is this multiculturalism with ethnics, home-building multiculturalism avant la lettre? In the following section, we discuss another part of Frank's story that displays close similarities to Heldke's notion of a colonial food adventurer.

\section{Classic food adventuring?}

In his early 20s Frank lived and worked in British Borneo, a colonial outpost at the time. He presents a classic account of food adventuring:

\footnotetext{
while I was in the cathedral compound I befriended the ... cook who was Chinese from Hong Kong. He used to go shooting for flying fox. So I ate flying fox. He said it's very important in skinning it not to let the skin come in contact with the meat because of-there's a particular disease which bats give, the name of which escapes me. That would - if the meat were contaminated you could get very sick. So I took the chance that he'd skinned it properly.
}

According to Heldke, a quintessential part of food adventuring is the eating of 'strange' meats and this can be seen as a display of bravery and intrepidness. Strange meats can include the non-customary part of animals, animals not usually eaten by food adventurers such as dogs, or game animals such as antelope or zebra. Exotic meat can comprise those animals that involve some form of danger, such as the fugu fish or animals that are rare or endangered. These tropes are present in this account as is a fear of less-than-hygenic food preparation. Cecelia Leong-Salobir (2011: 132) writes about British colonialists in Asia relying on and respecting 'local' domestic servants to run their home kitchens, yet at the same time fearing they may bring dirt and disease. It was an unresolved tension and one could read this to be present in Frank's adventuring with flying fox meat.

We note, however, that Frank tells us he lived in a kampong alongside local Malay and Chinese families, and this suggests his relationship to the Other was not as abstract as the caricature of the colonial food adventurer indicates. At that time, he had a new-born and mixed-race child with his Chinese wife. The dynamics of othering and food adventuring here are complex. Frank is a white Anglo-Australian expatriate in a British colony. At the same time, he is home-building with ethnics.

Of course, home-building mixed-race multiculturalism can be inflected by gendered 
colonialism and exoticisation, the specificities of which do not come through Frank's self presentation in relation to Asia, but were part of circulating ideas in the Anglocolonial imagination in Australia and British colonies. Frank was in British Borneo for two years and then returned to Australia. His ability to be mobile in these ways is also part of a certain kind of gendered, classed and white Anglo-racialised privilege.

Twenty years later, he was appointed to Australia’s first foreign aid project in subsaharan Africa, specifically in Kenya. He worked and lived there for six years and then for four years in Tanzania as 'mobile professional' and 'privileged migrant' (Fechter \& Walsh 2010). Although Frank is Australian and his nationality matters, he is also a 'Western migrant' in the sense of benefiting from racialised social hierarchies established by British colonialism and drawing on ideas and technologies in his work and home life informed by the 'collective imagination of Westerners' (Fechter \& Walsh 2010: 200). He describes living in compounds that separate him from the locals. And so while Kenya and Tanzania were both newly independent of British colonial rule, Frank describes living a classically expatriate and colonial lifestyle in terms of employment packages that included flights, paid schooling, segregated living arrangements with servants, and membership of golf and fishing clubs. Colonial society is not singular but is itself stratified by occupation-missionaries, civil servants, administrators, retired white farmers - and class, and across this diversity there can be 'remarkable cohesiveness' as expatriates often share the same attitudes, past-times and common sense of purpose (Korpela 2010: 1312).

Against this backdrop we can read the next quote, in which Frank is recounting eating habits in Africa where he worked as an expatriate aid worker:

\footnotetext{
I don't say I'm a connoisseur of game meat but I can say that eland and impala are good to eat. Warthog is as good as pork; less fatty but it's quite good. African Cape buffalo is terrible. It's stringy and red and hard. We tried it twice and each time my wife developed a severe migraine. So we decided that wasn't really what we-but sometimes that was what they brought back. We decided not to have any more of it.
}

The quote, with its ‘colonial tropes’ of African wildlife (Fechter \& Walsh 2010), seems quintessential food adventuring: here are all the hallmarks of exotic meats, intrepidness, masculinity and colonialism.

In a more contemporary reference of eating in Singapore, the next quote is more 
ambiguous. 'I learned to eat durian ... But durian I like. You're not supposed toEuropeans are not supposed to like it. It does have a bit of a smell of rotting flesh but it's very-I find it very sweet and the texture is very good. I do have a story about durians that.' Durian is notorious amongst many white people as being difficult to eat. In fact, for Heldke, this fruit constitutes the quintessential Asian food adventure for white people. Of course, while durian is not universally popular among Asians, it does have an iconic status as an Asian fruit. Indeed for many Asians, it is the prince of fruit, and western white demonisations of durian are seen as evidence of racism. Frank says he deliberately taught himself to learn to like a food that 'Europeans' are not supposed to like. Whilst this can be seen as an instance of eating the Other for self-distinction, his family and friendship connections to Asia have to be remembered when we analyse this data. This account can also, at the same time, be interpreted as a way to show respect for a valued food and to foster inter-cultural connections (Narayan 1997). As Ian Cook (2008) has noted, it is possible to be colonial and anti-colonial in our eating habits at the same time because people's biographies are heterogeneous and self-disruptive: 'There are experiences, sensations, dreams, memories and stories that can be told about little bits and bobs of deliberate and accidental border crossing and cross-cultural food solidarities in different people’s lives' (2008: 828).

A more straightforward form of eating the Other according to Heldke and Hage is that of white people circumscribing what authentic ethnic food should be like. Food, ingredients and restaurants need to be 'authentic,' defined as unchanging and unmodern. Thus, the food adventurer may know 'better' than the ethnic cook what a dish should be like. We can see some of this below, when again, Frank as a white mobile professional, this time in India recites a story about curry.

So I enjoyed the food that I had in India but I did make a curious observation. The Indian food which I discovered then that I - it's not even popular in Sydney now - is Mughlai food. Mughlai being the way of describing the food that the Mughal's ate. They call it a curry but it's not - it's almost not what I call a curry; it's a soft, creamy, white mixture flavouring. I find the taste much to my liking. I'm not that strong on very strong curries.

Frank reproduces distinction for himself through his ability to authenticate. As Heldke points out what constitutes authenticity in relation to food is actually confusing and contradictory. Nevertheless, white food adventurers like to see themselves as 'outsider experts on an ethnic cuisine, more knowledgeable than most insiders, and thus able to 
point out the inaccuracies in insiders' presentations of their own cuisines. Such adventurers seek to become the honorary insider, the outsider whose knowledge gives them the right to special treatment' (Heldke 2003: 29).

As Duruz (2010) writes, we need to attend as researchers to the dishes or ingredients invoked in accounts of food adventuring. Curry is a highly symbolic dish in relation to British colonialism. The term itself is complex and is not used by Indians in the same way as white British or Australians do; in fact, its very 'authenticity' is questionable (Narayan 1997). Curry powder itself is a British colonial 'invention.' Curry in Britainnow more popular than roast beef-is trumpeted by the state and popular media as the signifier of white Britain’s ‘tolerance.' But as Gunew and others note there are strict limits on what kind of, and how much, difference will be tolerated.

\section{Domesticating difference}

Different dynamics of eating the Other and food adventuring are evident in Frank's account, in which are calibrated food relations connected to ethnic groups and historical moments. Yet, the prospect that some food adventures would punctuate Frank's home living has not proved to be the case. Thus an interesting theme in Frank's story is the way in which eating at home with the Other is rendered unremarkable and undetailed. Of food with his first wife he says: 'I'm not sure there was anything notable about Springvale [a suburb in Melbourne] in terms of cuisine. We just-well of course by then that was — we'd already established in the house that my wife cooked rice and we went to China Town for meals. So that was more of the normal type of fare that we had.' Of his return from Africa to Australia with his second wife he comments: 'Then we went back to Canberra. I worked in Canberra for five years. There was nothing terribly remarkable about that. I really tried to think if there was anything that was different ... So in Canberra we just lived normal Australian lives.' Given the 'enthusiasm' for Asian foods he displays from his travel accounts, one could expect a continuing excitement about the food his Asian wives prepared. Instead there is a repeated rendering of this food as 'normal.'

One way to read these quotes is as confirmation of everyday multiculturalism (Wise \& Velayutham 2009). In this regard, we might see Frank as normalising the Other as ordinary, as ‘fully' Australian. Interpreted this way, he does not represent Asian food as something that spices up the blandness of white culture. However, there is so little 
colour in these accounts. Difference appears to be completely invisibilised. These are not the rich stories of everyday multicultural encounters seen and critiqued in other studies (Duruz 2005, 2010; Wise \& Velayutham 2009). How do we understand this?

Frank's talk about food is more detailed when he enters the public domain. The domestic realm and food are culturally coded as feminine, particularly in an era before television programs like Masterchef, which embodies a new ebullient 'foodie masculinity.' So in some ways it is not surprising Frank gives little detail. However, we need to understand the racialised relations in his accounts. In one Orientalist version of eating the Other, the Other is interesting and important insofar as he or she serves to illuminate the white person, to render his or her life more authentic. The Other can do this because they are seen as more exciting, intense, dangerous, authentic, spiritual, sensuous: they are radically Other (Heldke 2003: 148). But Frank does not reproduce this Orientalist narrative in relation to eating at home. He does not mark his food as strange or Other; but in so doing he erases difference. He invisibilises not only the domestic labour of food-work by women, but also their Otherness. This suggests that while Frank relishes certain food and ethnic difference in the public domain, he presents an account of containing difference in the private domain. When authors like hooks and Narayan discuss the domestication of the Other, they are pointing to the containment of difference: its rendering as safe and knowable. In relation to food, this can be seen as devaluing food as cultural capital at home in a process of producing the cosmopolitan white self.

This story on mixed race home-building multiculturalism complicates Hage’s privileging of home-building as a form of 'good' multiculturalism. The gendered dynamics of food-work missing from Hage’s theorising; so too are the specificities of various inter-cultural interactions. Another way of understanding Frank's silence about the details of food in his home life is that while he clearly has turned to Asia in relation to the public domain, it is possible that he is also continuing to position his Angloethnicity as the active subject and the Asian Other as passive object. For Hage and others, this rendering of the object of another's power is at the centre of much Othering in ethnic food encounters. Athena Nguyen (2005) refers to the Other in this dynamic as 'object-people' (2005: 52). We are not suggesting that the women lacked agency, but rather that this is how they are constructed in Frank's account. 
So how do we understand the dynamic here? As we have indicated, Australia's particular perception of Asia is inflected by Orientalism, fear and desire, in that the category Asian is seen as profoundly and irresolutely Other. At the same time, for political, economic and security reasons Australia has also sought to interact with Asia. As Nguyen writes: 'this at times weighed heavily on the white Australian psyche which has struggled to negotiate between the competing tensions of "multicultural" and racially tolerant policies and a lingering fear of "the teeming millions" of its Asian neighbours' (2005: 45). In Frank’s story we have a white Anglo-Australian married to two Asian women, in an era when parts of Australia were turning to Asia while other parts remained fearful. Indeed, it is important to remember here that the White Australia policy was in formal force until 1972.

However, Frank does not seem anxious about how his wives experienced themselves as food-makers or what he and they ate at home; rather, he is disinterested in those experiences. Rather than white food being presented as routine and mundane, in Frank's accounts Asian food is. The capacity to be disinterested is in itself a privilege afforded not only by masculinity but by Anglo-ethnicity as well. It hints at the domestication of the threat of difference and a denial of the lived realities of these women's racialised lives in Australia. Hage suggests that home-building multiculturalism can still be experienced as homely even when it is grounded in what he calls a 'dominant mode of patriarchal homely interactions' (1997: 117). Feminists would argue that Hage’s construction of the homely is problematic. In Frank's case, we have inter-racial homebuilding multiculturalism in which power dynamics are not only gendered but racialised against a historical backdrop of Australia's Orientalism, its fear of Asia and a desire to be seen as multiculturally tolerant (Nguyen 2005). Thus, we might gloss this story as multiculturalism with ethnics but without ethnic subjects. Frank's story challenges neat discourses about Australia's fear of Asia, but it illustrates the nuanced ways in which Australia's relationship with Asia has, and continues to be, tinged with the politics of racism embedded in histories of colonialism.

\section{Conclusion}

In this paper we have presented Frank’s 'entangled' story. Entangled here are skeins of white expatriate masculinity, eating out and eating in multiculturalism with ethnics and colonial food adventuring. As with other stories of everyday multiculturalism eating, 
(Duruz 2005, 2010), Frank's story troubles neat categories. Through our themes of white food, ethnic food socialities and domesticating difference, we have shown how his storying disturbs notions of cosmo-multiculturalism without ethnics and of homebuilding multiculturalism with ethnics. In particular, we have emphasised the importance of theorising different racialised and gendered food encounters and their multicultural histories. Thus, it matters how that Frank imagines Asia, Asians, Africa and Australia and his gendered relation to those parts of the world. Putting it bluntly, what we eat with which Other, and in which context, matter analytically and politically to our conceptualisation of Eating the Other.

Our overall argument is that we can see Frank positioning himself from the 1950s in a turn to Asia that marks him as a proto-Australian food multiculturalist. Frank turned to Asia at a time when the White Australia immigration policy was still robust, when Britain still governed numerous Asian colonies, and when various authors claim there was a strong sense of nostalgia among Australians for Anglo-comfort food. One side of Frank developed a sense of identity that challenged and indeed subverted dominant Anglo-white identities. He did not proclaim this was a project of resistance; but he certainly went far beyond the patronising claims to inclusiveness of Australians who pride themselves when adventuring into Asian restaurants. At the same time, Frank fits into classic food adventuring, the colonial 'food savant' (Narayan 1997), trading in cultural knowledge about ethnic food and its authenticity and reproducing a certain white Anglo-masculinity. This is not to say that Frank is unique in the confusion of his multicultural self-presentations: many of us are contradictory in how we understand ourselves, particularly in relation to race.

Our argument is that Frank represents a messy blend of cosmo- and home-building multiculturalism. In this, we can the contours of what we might call an Australian 'cosmopolitan modern masculinity.' This is a complement to Sheridan's notion of cosmopolitan modern femininity. The idea of being modern and cosmopolitan through cooking the Other's food at home was promulgated in Australia by the Women's Weekly magazine from the 1950s. What we might call Australian cosmopolitan modern masculinity represents the turn from Britain to Asia, [actually, wasn't the significant turn from Britain to the USA and hence the Asia-Pacific World after World War II, and during the Cold War era?] and is performed through food in the public domain across 
different countries. In this mode of masculinity, there is an inexpressivity around food, and eating at home with Asian women offers the least capital for performing a multicultural self.

Whiteness and masculinity are produced relationally; Frank's version of masculinity is enabled by contrast to an everyday Asian domestic femininity and a non-multicultural Anglo-Australian masculinity. Shona Hunter (2010) has written of the turn away in Britain through its state multiculturalist policy from the idea of civilising the colonised Other to the need for civilising the white man. What she means is that white men are now seen as in need of producing a more 'multicultural' masculinity. In relation to Australia, the so-called egalitarian ethic and the idea of hospitality and giving opportunity to migrants can be understood in term of white masculinity. The Australian take on this version of masculinity and whiteness is critical. In Frank's case, it is produced through an openness to Asia through male friendship and heterosexual relations with Asian women.

What does this mean for food multiculturalism pedagogies, and discussions on education around ethnic food. Heldke proposes an anti-colonial food pedagogy (2003). She argues that white food adventurers can be less colonising if they better understand the ethnic cultures of those whose food they eat. A more sophisticated view of how eating ethnic food has possibilities for public pedagogy comes from Narayan (2007). She suggests that Heldke's approach is at best naïve; and at worst dangerous, in that it can produce superficial, culturalist, depoliticised understandings of food and race. In her view, Heldke's anti-colonial food pedagogy cannot undo the structural privilege of colonial eaters. In fact, knowing culturalist information about food can lead to a renewal of white status. For Narayan, food multicultural education needs to more explicitly place food production and consumption in a material and political economy frame. This means examining the political, colonial, historical and cultural conditions under which 'ethnic food' is made, eaten and by whom. For Narayan, this approach may lead to a more collective project of social change.

How might we see Frank’s story as offering us another way into looking at food, multiculturalism and pedagogy in Australia. Food relations with the Other need to be placed in the context of specific colonial and imperial histories. At the same time, the specificities of the Other and the nature of their Othering needs examination. Frank's 
culinary biography contains various intercultural interactions with different Others. Racialised and ethnicised specificities matter. There are different power dynamics to the ethnic and colonial relations being presented in Frank’s account. Gender is critical here, as masculinity and femininity intersect with race and ethnicity. As a result, we can see that through food Anglo-masculinity can be 'multicultural' in different ways from Anglo-femininity. In particular, the private and public operate in different ways as places for food inter-cultural encounters and claims about identity. Food itself is unevenly valued as cosmopolitan capital. French food is imagined differently from Indonesian food. It also matters what version of state and popular multiculturalisms are circulating for the kind of subjectivities which can be presented. What is critical then is there are many forms and contents of Othering.

What we need to develop, extending the work of Ang and Duruz, is a 'pedagogy of multicultural entanglement.' This would get at the oscillations and variegations in eating the Other and the colonial and anti-colonial dynamics we can see at play between masculinity and femininity, specific ethnicities, multiculturalism and imperialism, eating in and eating out, Anglo and Other, and Other and Other. This means we can interrogate more closely what we imagine to be the connection made through food with, and to, the Other, at concrete and ontological levels. What Other, in fact, are we eating? This new pedagogy, to redeploy Sharma's words (2006) would think through the kinds of encounters with otherness that multicultural pedagogies perform and engender.

\section{Acknowledgements}

We are grateful for the financial support we received from both the Cosmopolitan Civil Societies Research Centre and the Faculty of Social Sciences in the University of Technology Sydney. We would like to thank Frank for the interviews, and Elaine Lally and Nick Hopwood for their helpful comments on the draft of this paper.

\section{Reference List}

Anderson, K. 1993, 'Otherness, Culture and Capital: Chinatown’s Transformation Under Australian Multiculturalism,' in Multiculturalism, Difference and Postmodernism, (eds) G.L. Clark, D. Forbes \& R. Francis. Longman Cheshire, Melbourne: 58-74.

Ang. I. 2000, 'Introduction: Alter/Asian Culture Interventions for $21^{\text {st }}$ Century Australia,' in Alter/Asians: Asian-Australian Identities in Art, Media and Popular Culture, (eds) I. Ang, S. Chalmers, L. Law \& M. Thomas. Pluto Press, Annandale:, xiii-xxx. 2003, 'From White Australia to Fortress Australia: The Anxious Nation in the New Century,' in Legacies of White Australia: Race, Culture and Nation, (eds) L. Jayasuriya, D. Walker, and J. Gothard. University of Western Australia Press, Crawley, WA: 51-69. 2004, 'Between Asia and the West: The Cultural Politics of Food,' Life Writing, vol. 1, no. 1: 147154. 
Byrne, B. 2006, White Lives: The Interplay of 'Race,' Class and Gender in Everyday Life. Routledge, London \& New York.

Cameron, E. 2012, 'New Geographies of Story and Storytelling,' Progress in Human Geography, online edition, doio: 10.1177/0309132511435000: 1-20.

Carter, D. 2008, Dispossesion, Dreams and Diversity: Issues in Australian Studies. Pearson Education Australia, Frenchs Forest.

Chan, S. C. 2010, 'Food, Memories, and Identities in Hong Kong,' Identities: Global Studies in Power and Culture, vol. 17, no. 2-3: 204-227.

Cline, S. \& Angier, C. 2010, The Arvon Book of Life Writing: Writing Biography, Autobiography and Memoir. Methuen, London.

Cook, I. 2008, ‘Geographies of Food: Mixing,' Progress in Human Geography, vol. 32, no. 6, 821-33.

Cook, I. \& Harrison, M. 2003, 'Cross-over Foods: Re-materializing Post-colonial Geographies,' Transactions of the Institute of British Geographers, no. 28: 296-317.

Creswell, J. 2005, Educational Research: Planning, Conducting and Evaluating Quantitative and Qualitative Research, $2^{\text {nd }}$ ed. Prentice Hall, Upper Saddle River, NJ.

Duruz, J. 1999, 'Food as Nostalgia: Eating the Fifties and Sixties,' Australian Historical Studies, vol. 30, no. 113: 231-50.

2001, 'Home Cooking, Nostalgia, and the Purchase of Tradition,' Traditional Dwellings and Settlements Review, vol. 12, no. 2: 21-32.

2005, 'Eating at the Borders: Culinary Journeys,' Environment and Planning D: Society and Space, vol. 23, no. 1: 51-69.

2010, 'Floating Food: Eating “Asia” in Kitchens of the Diaspora,' Emotion, Space and Society, vol. 3: 45-49.

2011, 'At the Table with the Hungry Ghosts: Intimate Border Work in Mexico City,' Cultural Studies Review, vol. 17, no. 2: 198-218.

Elder, C. 2003, 'Invaders, Illegals and Aliens: Imagining Exclusion in a "White Australia,”' Law Text Culture, vol. 7, no. 1. Online, available at: http://ro.uow.edu.au/ltc/vol7/iss1/10 [Accessed June 23 2012].

Fechter, A-K. \& Walsh, A. 2010, 'Examining “Expatriate” Continuities: Postcolonial Approaches to Mobile Professionals,' Journal of Ethnic and Migration Studies, vol 36, no. 8: 1197-210.

Fiske, J., Hodge, B. \& Turner, G. 1987, Myths of Oz. Allen and Unwin, Boston.

Flowers, R. \& Swan. E. 2011, 'Eating at Us: Representations of Knowledge in the Activist Documentary Film Food Inc.' Studies in Education of Adults, vol. 43, no. 2, Autumn: 23450.

(eds) 2012a, Australian Journal of Adult Learning, Special Issue: ‘Food Pedagogies,' vol. 52, no. 3, November. 2012b, ““Teaching People to Suck Eggs”: Pedagogies of Food Activism,' Australian Journal of Adult Learning, Special Issue: 'Food Pedagogies,' vol. 52, no. 3: 121 (eds) 2013 (forthcoming), Food Pedagogies. Ashgate Publishing, London.

Gray, A., 2003, Research Practice for Cultural Studies: Ethnographic Methods and Lived Cultures. London, Sage.

Gunew, S. 1993, 'Against Multiculturalism: Rhetorical Images in Multiculturalism, Difference and Postmodernism,' in Multiculturalism, Difference and Postmodernism, (eds) G.L. Clark, D. Forbes \& R. Francis. Longman Cheshire, Melbourne: 38-53.

Hage, G. 1997, 'At Home in the Entrails of the West: Multiculturalism, Ethnic Food and Migrant HomeBuilding,' in Home/world: Space, Community and Marginality in Sydney's West, (eds) H. Grace, G. Hage, L. Johnson, J. Langsworth \& M. Symonds. Pluto, Annandale: 99-153.

Heldke, L. 2003, Exotic Appetites: Ruminations of a Food Adventurer. Routledge, London \& New York Holtzman, J. 2006, 'Food and Memory,' Annual Review of Anthropology, vol. 35, October: 361-78.

hooks, b. 1992, 'Eating the Other,' in Black looks: Race and representation. South End Press, Boston: 21-39.

Hunter, S. 2010, 'What a White Shame: Race, Gender, and White Shame in the Relational Economy of Primary Health Care Organizations in England,' Social Politics: International Studies in Gender, State and Society, vol. 17, no. 4, Winter: 450-76.

Jayasuriya, L. \& Pookong, K. 1999, The Asianisation of Australia?: Some Facts about the Myths. Melbourne University Press, Carlton, Victoria.

Johnston, J. \& Baumann, S. 2010, Foodies: Democracy and Distinction in the Gourmet Foodscape. Routledge, New York \& London.

Korpela, M. 2010, ‘A Postcolonial Imagination? Westerners Searching for Authenticity in India,' Journal of Ethnic and Migration Studies, vol. 36, no. 8: 1299-315. 
Leong-Salobir, C. 2011, Food Culture in Colonial Asia: A Taste of Empire. Routledge, London \& New York.

Luke, C. (ed.) 1996, Feminisms and Pedagogies of Everyday Life. State University of New York Press, Albany, NY.

Miller, J., \& Deutsch, J. 2009, Food Studies: An Introduction to Research Methods. Berg, Oxford \& New York.

Narayan, U. 1997, Dislocating Cultures: Identities, Traditions, and Third World Feminism. Routledge, London \& New York.

Nguyen, A. 2005, 'I'm Not Racist, I Eat Dim Sims!: The Commodification and Consumption of Asianness within White Australia,' Graduate Journal of Asia-Pacific Studies, vol. 3, no. 2: 45-57.

Perera, S. 1999, 'Whiteness and its Discontents: Notes on Class, Gender, Sex and Food in the Year of Hanson,' Journal of Intercultural Studies, vol. 20, no. 2: 183-98.

Plummer, K. 2001, Documents of Life 2: An Invitation to Critical Humanism. Sage, London.

Polkinghorne, D. 1988, Narrative Writing and the Human Sciences. State University of New York Press, Albany.

Portelli, A. 1998, 'What Makes Oral History Different?,' in The Oral History Reader, (eds) R. Perks \& A. Thomson, Routledge, London \& New York.

Probyn, E. 2000, Carnal Appetites: FoodSexIdentities. Routledge, London \& New York.

Said, E. 1978, Orientalism. Pantheon Books, New York.

Sandlin, J., Schultz, B. \& Burdick, J. (eds) 2009, Handbook of Public Pedagogy: Education and Learning Beyond Schooling. Routledge, London \& New York.

Sharma, S. 2006, Multicultural Encounters. MacMillan Palgrave, Houndsmills, Basingstoke.

Sheridan, S. 2000, 'Eating the Other: Food and Cultural Difference in the Australian Women's Weekly in the 1960s,' Journal of Intercultural Studies, vol. 21, no. 3: 319-29.

Skeggs, B. (ed.) 1995, Feminist and Cultural Theory Process and Production. Manchester University Press, Manchester.

Stacey, J. 1994, Stargazing. Hollywood Cinema and Female Spectatorship. Routledge, London. 1995, 'The Lost Audience: Methodology, Cinema History and Feminist Criticism,' in Feminist and Cultural Theory Process and Production, (ed.) B. Skeggs, Manchester, Manchester University Press: 97-118.

Supski, S. 2997, It Was Another Skin: The Kitchen in 1950s Western Australia. Peter Lang, Frankfurt. Sutton, D. 2001, Remembrance of Repasts: An Anthropology of Food and Memory. Berg, Oxford.

Swan, E. 2007, 'Blue Eyed Girl? Jane Elliott's Experiential Learning and Anti-Racism,' in Handbook of Experiential Learning and Management Education, (eds) M. L. Reynolds \& R. Vince, Oxford University Press, Oxford: 202-20.

Walker, D. 1999, Anxious Nation: Australia and the Rise of Asia 1850-1939. University of Queensland Press, St. Lucia.

Welton, M. 2003, “'No Escape from the Hard Things of the World': Learning the Lessons of Empire,' International Journal of Lifelong Learning, vol. 22, no. 6: 633-51.

Wise, A. \& Velayutham, A. (eds) 2009, Everyday Multiculturalism. Palgrave Macmillan, Basingstoke.

Wow Blacktown! Multicultural Fiesta 2011. Online, available: http://au.wherevernow.com/?event=137651589635180 [Accessed 15 June 2012]. 